\title{
Coffee Farm Agrotourism Model as Fluctuating Income Solution and Environmental Uncertainty in Kabupaten Bener Meriah and Aceh Tengah
}

\author{
Siti Maimunah', Hamdiah², Yohana Dian Putri ${ }^{3}$ \\ ${ }^{1,2,3}$ Faculty of Economics and Business, Universitas Malikussaleh, Indonesia \\ sitimaimunah@unimal.ac.id,hamdiah@unimal.ac.id,yohanadianputri@unimal.ac.id
}

\begin{abstract}
Coffee is a leading commodity and a source of community income where coffee plantations are managed and owned by the community. This study aims to determine the effect of coffee plantation agro-tourism development on the solution of community income fluctuations and environmental uncertainty. This study uses primary data sourced from a questionnaire of as many as 170 respondents conducted by purposive sampling method. This research method uses a causal model survey method using path analysis techniques with Structural Equation Models (SEM). The results of data analysis obtained coefficient and significance values that illustrate that coffee plantation agrotourism has a significant effect on environmental uncertainty with a significant value of 0.000 which means that if coffee plantation agro-tourism is developed, it will be a solution to environmental uncertainty. Furthermore, coffee plantation agro-tourism also significantly affects people's income with a significant coefficient value of 0.000. If coffee plantation agro-tourism is developed, it will solve community income fluctuations. The role of the government has no effect on people's income with a significance value above 0.05 and does not affect environmental uncertainty with a significance value above 0.05. It shows no government influence in the development of coffee plantation agro-tourism. Moderation: The government's role is still fragile, with a negative coefficient value and a significant value greater than 0.05. This means that the government has not played a role in making coffee plantation agro-tourism one of the tourist destinations in Bener and Central Aceh districts. The conclusion is that the development of coffee plantation agro-tourism is a factor that can be used to increase people's income which is currently fluctuating because the coffee harvest influences it. The development of coffee plantation agrotourism is also a factor that can overcome environmental uncertainty, where farming communities can use coffee fields as gardens that produce coffee fruit and at the same time as agrotourism that can create new jobs, open up business opportunities and educate visitors about coffee.
\end{abstract}

\section{Keywords}

agrotourism; income;

environmental uncertainty

\section{Introduction}

Tourism development is one of the leading sectors at this time. The tourism sector provides opportunities for the growth of various economic businesses carried out by the community and opens up formal and informal employment opportunities for the community. In its development, tourism has experienced much expansion. It has been diversified in various forms, so that the tourism sector in addition to developing into a creative service industry sector, is also an economic sector that experiences the fastest 
growth among other economic sectors in the world. The rapid development of tourism requires new breakthroughs in anticipating the saturation that may occur to tourists. This raises the emergence of various objects and alternative tourist attractions that are more varied or tourism with special interests such as: agro tourism, spiritual tourism, adventure tourism, and other alternative tourism.

Coffee for the people of Bener Meriah and Central Aceh is the pulse of the economy where the community manages $80 \%$ of coffee plantations and depend on coffee plants for their livelihood, the development of coffee plantation agro-tourism as a manifestation of the creativity of coffee farming communities who develop marginal land into productive land is starting to become a serious concern. And began to show progress for developing this coffee agro-tourism for farmers. The process of developing coffee plantation agrotourism in reality still faces various problems, in general the problems that occur are the lack of government attention in infrastructure policies and the role of the community is not optimal, in responding to business opportunities from the existence of tourism activities in the village. This is based on the challenges of change. Social life of the community in several aspects, including changes in people's mindsets, changes in social society, changes in ownership/materials. First, the change in people's mindsets and attitudes towards social and cultural issues around them resulted in the distribution of new patterns of thought adopted by the community as a modern attitude. Second, the change in people's behavior concerns the issue of changing the old social systems and implementing the new social system. Furthermore, third, changes in material culture involve changes in cultural artifacts used by the community, such as clothing models, photographic works, technology, and so on which continue to change from time to time according to the community's needs.

In line with Subowo's opinion (in Tati Budiarti, et al, 2013:201) agricultural land will create jobs and increase farmers' income. In addition, the development of agro-tourism activities can conserve resources, preserve local wisdom and local technology, and increase the income of farmers or communities around agro-tourism. This coffee plantation agrotourism is the first step in making a breakthrough in agricultural tourism in Bener Meriah and Central Aceh Regencies.

The economic condition of the population is a condition that describes human life that has economic score (Shah et al, 2020). Economic growth is still an important goal in a country's economy, especially for developing countries like Indonesia (Magdalena and Suhatman, 2020).

The tourism sector has a role in the economy of an area to increase people's income by creating and adding fields and job opportunities for the community around the environment where agro-tourism is located. Such as accommodation businesses, restaurants, tour guides, travel agencies and other services. In addition, the tourism industry also contributes directly to the environment in the form of making and repairing roads, ports, airports, hygiene and health programs, all of which can provide benefits and pleasure for the community in the area concerned and visiting tourists.

Under research by Indah Permata Sari, et al., they stated that the development of a coffee plantation as an agro tourism object in the Kampung Mushroom Ujung area carried out by a group of people has had a positive impact on the surrounding community, including employment opportunities, changes in livelihoods, and changes in income. The development of coffee plantations as agro-tourism objects has changed the livelihoods of those who used to be coffee farm laborers now become workers in agro-tourism, who used to be pedicab drivers to become workers in coffee agro-tourism as guest servants who want to pick coffee. With the development of coffee plantations around them, they admit that this is an opportunity for them to change professions. 
By doing this research, it is expected to reveal and analyze the development of coffee plantation agro-tourism as a solution for people's incomes that fluctuate due to the influence of the coffee harvest season and farmers' decisions in land use/coffee plantations and the design of agrotourism development in the field. By building synergy, awareness, and agreement of the parties involved (community, government and private sector) in the development of coffee plantation agro-tourism in Bener Meriah and Central Aceh districts.

\section{Review of Literature}

Agrotourism is an agribusiness activity where local farmers offer tours of their farms and allow visitors to witness the growth, harvesting, processing of local food that would not be found in their native area (Tavare in Maruti, 2009). Furthermore, (Mazilu and Iancu 2006) stated that agrotourism is a tourist activity to help farmers get additional farm income, which is their main source of income.

Formally, (Wolfe and Bullen in Budiasa, 2011) define agrotourism as an activity, business, or business that combines the principal elements and characteristics of agriculture and tourism and provides an experience to visitors that encourages economic activity and has an impact on farming and community income. Traditional agritourism only offers vacation packages with temporary stays for visitors to enjoy the natural resources of farming and farmers get a small amount of additional income. Furthermore, in modern agro-tourism, farmers seem to have more initiative to invest in offering more agro-tourism products in the hope of making a real contribution to their farm income. More clearly defined by Sutjipta (2001), agro-tourism is an integrated and coordinated system of activities for developing tourism and agriculture about environmental conservation and improvement of community welfare.

According to Suyastiri (2012), the implementation of the concept of agro-tourism will improve the welfare of farmers, preserve the natural environment and inhibit farmers' intention to change land functions.

By developing agro-tourism that emphasizes local culture in utilizing land, farmers' income is expected to be increased while preserving land resources and maintaining local culture and technology, which are generally under their natural environment (Sanjaya, 2013).

Purwadarminto in Astuti (2013), income is the amount of income received by a person in the form of money or goods resulting from work or effort. There are three components of income, namely:

a. Income in the form of money, namely income in the form of regular money and which is usually received as remuneration or contra-achievement.

b. Income in the form of goods, namely everything that is regular and ordinary but is always in the form of remuneration and is received in goods.

Income is not income is anything that is redistribution transfer and usually makes changes in household finances. People's income is very dependent on the business field, level of employment, general education level, productivity, business prospects, capital, and others. The factors above are the cause of differences in the level of income of the population. Indicators of age, working time, education level, and income distribution will indicate the aspect of achieving equitable distribution of people's income (Gini Ratio, 2007).

The tourism sector provides opportunities for the growth of various economic businesses carried out by the community and opens up formal and informal employment opportunities for the community. The tourism sector also brings together two or more 
different cultures; tourists gain experience from local cultures while residents play a type of education about local specific environments and earn income. Community participation has an essential role in the development of tourism, and the community must think in an integrated and long-term way to obtain benefits from the tourism sector, including increased skills, job opportunities, increased welfare, appreciation of cultural values, and benefits of environmental conservation (Brandon, 1996): Lopez and Gracia 2006.

Understanding environmental uncertainty according to Milliken (1987) environmental uncertainty is a person's sense of inability to predict something accurately from all social and physical factors that directly influence the decision-making behavior of people in organizations. Environmental uncertainty variables were measured using indicators: lack of information, inability to know results, and inability to determine probability.

Chenhall and Morris (1986) and Fisher (1996) in Astuti (2007) state that environmental uncertainty faced by a manager will affect the characteristics of the information he needs. The control environment is the collective impact of various factors on the creation, improvement, or reduction of the effectiveness of specific policies and procedures.

The management of tourism involves three components that are tasked and responsible: the community, the government, and business people. In these three components, the Government is more dominant in development because it follows the Government's duties as the implementation of the development tasks themselves (Siagian, 2011). The government's role in tourism development in outline includes providing infrastructure (both facilities and infrastructure) and expanding various forms of facilities. In accordance with government regulations relating to the development of natural tourist destinations, it is expected that the principles of conservation and nature conservation are taken into account by protecting against pollution, environmental damage, disturbance to the ecosystem or eliminating the attractiveness of conservation areas. Therefore, the development of nature tourism is expected to provide positive values and opportunities to improve the community's economic conditions.

Based on the explanation above, the hypotheses in this study are:

H1: Coffee plantation agro-tourism has a significant effect on plug-in solutions community income.

H2: Coffee Garden Agrotourism has a significant effect on Uncertainty The environment in the districts of Bener lively and Central Aceh.

H3: The role of the government has a significant effect on increasing income communities around agro-tourism sites.

$\mathrm{H} 4$ : The role of the government has a significant effect on environmental uncertainty.

H5: The role of the government in moderating the influence of coffee plantation agro tourism on Job satisfaction has a significant effect on people's income in Bener Merry District and Central Aceh.

H6: The role of the government in moderating the influence of coffee plantation agro tourism on environmental uncertainty in the districts of Bener Meriah and Central Aceh. 


\section{Research Method}

This research was conducted on the Seladang coffee plantation agrotourism and Arabica coffee plantation in Bener Meriah Regency and the Indonesian Coffee Gallery, Gunung Suku Village Coffee Garden in Central Aceh. This study used a causal model survey method using path analysis techniques. This study aims to confirm the theoretical model with empirical data based on the reasons. The survey referred to here is research that aims to determine and determine the temporary position of the variable (status quo variable) based on the existing data (status quo data), and the relationships between the variables studied can then be determined and conclusions are drawn. The research method used is the explanatory research method. The data collection technique used variable measurement using a questionnaire instrument in a questionnaire with a Likert Scale model. Questionnaires were distributed to 170 respondents in the four agro-tourism locations above. The questionnaire device involves four main variables, namely the instrument in the form of a questionnaire to measure coffee plantation agro-tourism, community income, environmental uncertainty, and the government's role.

\section{Results and Discussion}

\subsection{Results}

The natural potential of Bener Meriah and Central Aceh regencies, which are expanses of coffee plantations, can be developed as coffee plantation agro-tourism. The development of agro-tourism is related to central government programs that emphasize the improvement of the agro-tourism sector with agribusiness. Supporting this program requires the involvement of several parties in making the villages in Bener Meriah and Aceh Tengah into agro-tourism destinations by motivating the community to increase income and build public awareness in maintaining cleanliness, beauty, comfort, and an Islamic environment. Based on the questionnaire data analysis, the following results were obtained:

\section{a. Respondents Characteristics}

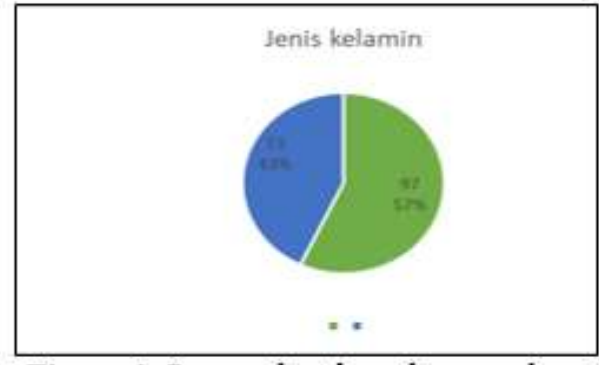

Figure 1. Respondent based on gender

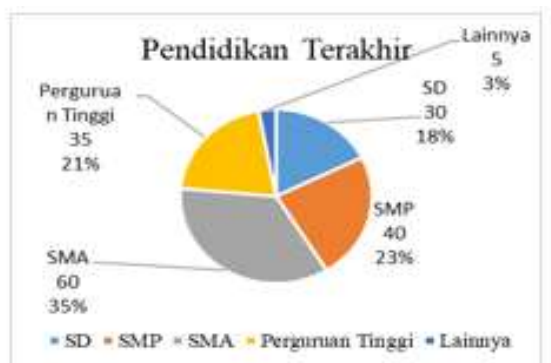

Figure 2. Respondent based on Education Background

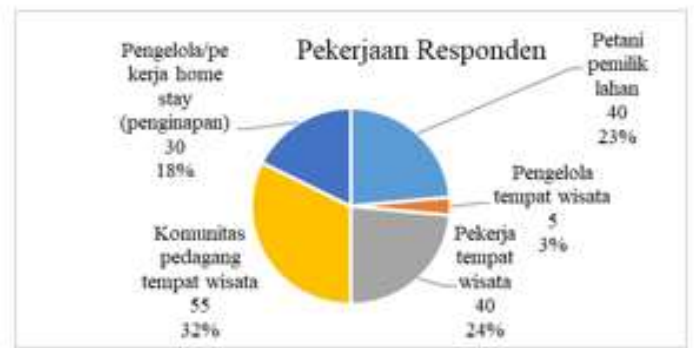

Figure 3. Respondent based on occupation

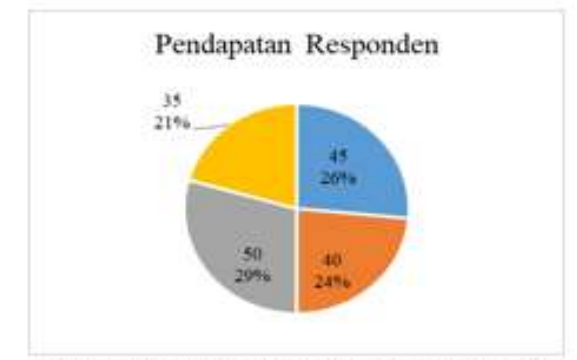

Figure 4. Respondent based on salary 


\section{b. Measurement Model (Outer Model)}

The analysis of the measurement model (Outer Model) aims to evaluate the validity (accuracy) and reliability (reliability) of a construct from the variables studied, namely, among others: (1) Convergent Validity (Average Variance Extracted/ AVE), and (2) Discriminant Validity and (3) Internal consistency/composite reliability. The results of the outer model analysis are shown in the following figure:

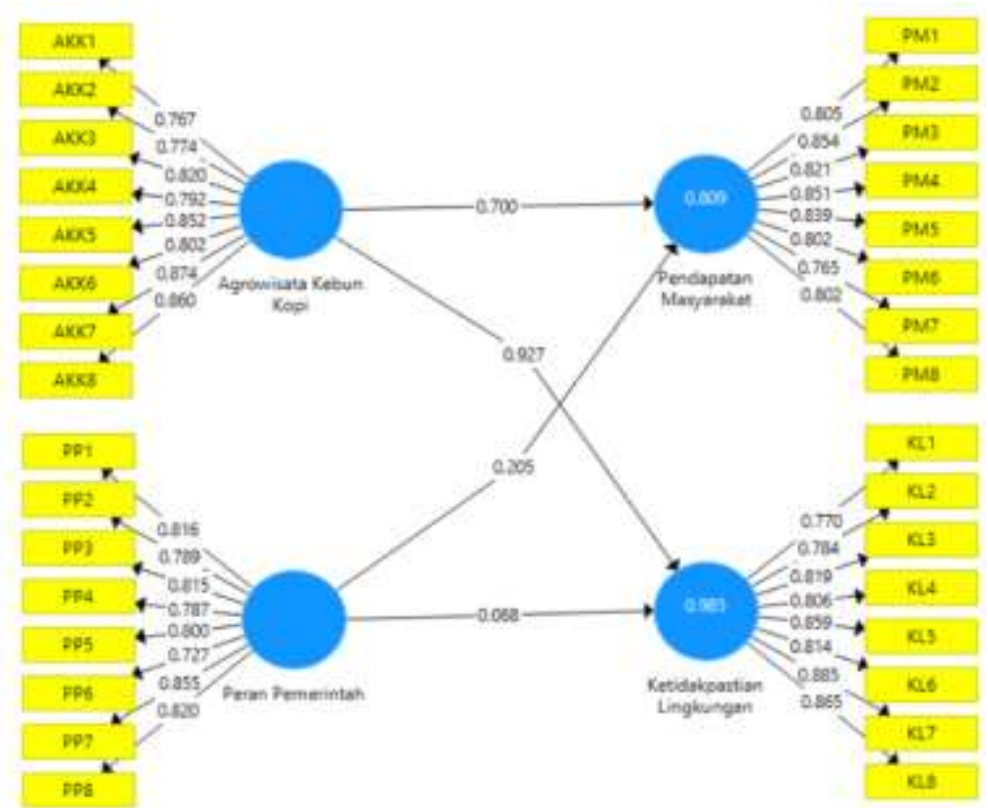

Figure 5. Outer Model Regression Results

\section{c. Structural Model (Inner Model)}

Structural Model Analysis (inner model) aims to test the research hypothesis. There are three parts that are analyzed in this structural model, namely: (1) Collinearity (Collinearity/Variance Inflation Factor/VIF), (2) Testing the significance of the structural model path coefficient (Structural Model Path Coefficient), (3) Coefficient of Determination (R). -Square).

\section{d. Structural Model Path Coefficient Significance Testing \\ 1. Sub structural 1}

Sub-structural 1 aims to determine the direct influence of coffee plantation agrotourism on people's income. And the direct influence of coffee plantation agro-tourism on environmental uncertainty. The results of the analysis of the inner model of Sub-structural 1 are shown in Figure 6. 


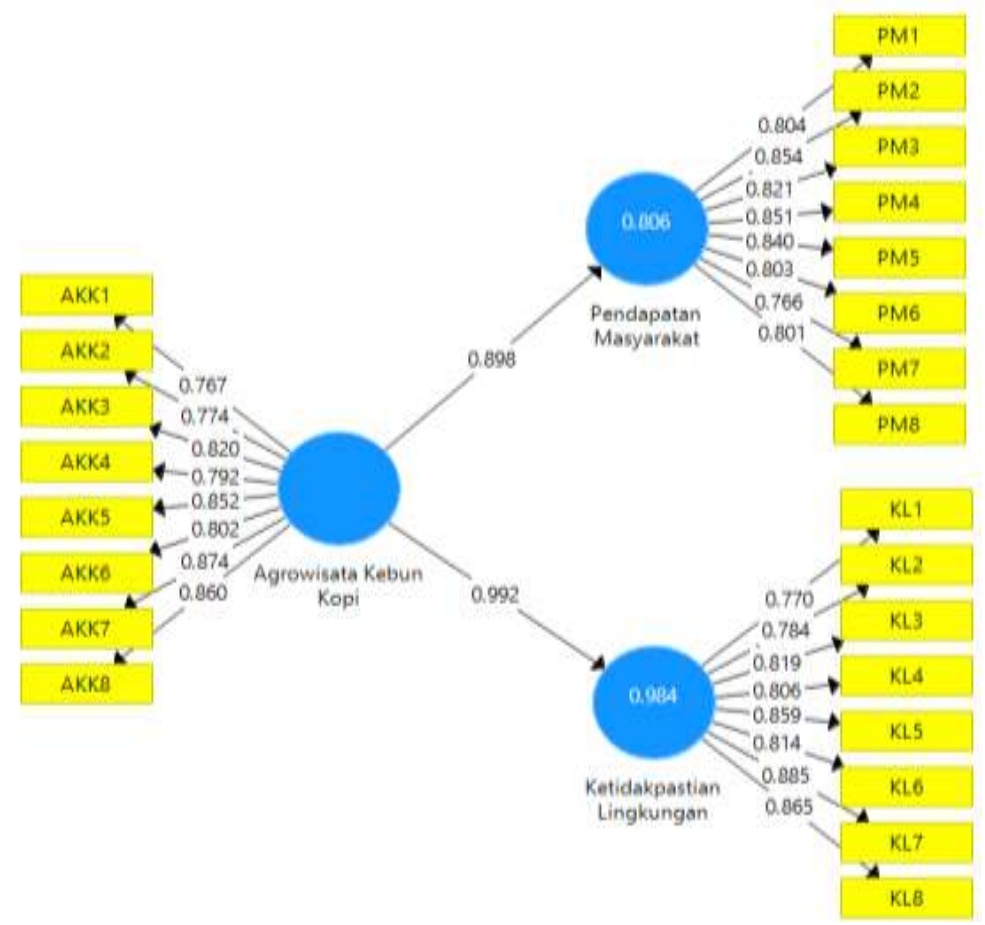

Figure 6. Inner Model Sub Structural 1

Based on the data shown in Figure 6 then summarized in Table 1.

Table 1. Testing the Significance of the Substructure Path Coefficient 1

\begin{tabular}{lcccc}
\hline \multicolumn{1}{c}{ Variables } & $\begin{array}{c}\text { Original } \\
\text { Sample } \\
(\mathrm{O})\end{array}$ & $\begin{array}{c}\text { Standard } \\
\text { Deviation } \\
(\text { STDEV })\end{array}$ & $\begin{array}{c}\text { T Statistics } \\
(|\mathrm{O} / \mathrm{STDEV}|)\end{array}$ & $\begin{array}{c}\mathrm{P} \\
\text { Values }\end{array}$ \\
\hline $\begin{array}{l}\text { Coffee farm agrotourism -> } \\
\text { Environmental uncertainty }\end{array}$ & 0,992 & 0,004 & 226,358 & 0,000 \\
\hline $\begin{array}{l}\text { Coffee farm agrotourism-> } \\
\text { Environmental uncertainty }\end{array}$ & 0,898 & 0,016 & 54,487 & 0,000 \\
\hline
\end{tabular}

Based on the data shown in Table 1, it can be explained that coffee plantation agrotourism has a significant effect on environmental uncertainty with a coefficient value of 0.992 and a significant value (p-value) of 0.000 (significant at the $1 \%$ level). This means that if coffee plantation agro-tourism develops well in the district of Benar Merry and Central Aceh, it will be able to minimize environmental uncertainty. Furthermore, coffee plantation agro-tourism has a significant effect on people's income with a coefficient value of 0.898 and a significance value ( $\mathrm{p}$; value) of 0.000 (significance). at the $1 \%$ level). This means that if coffee plantation agro-tourism is well developed, it will increase communities' income.

\section{Sub structural 2}

Sub-structural 2 aims to determine the direct influence of coffee plantation agrotourism on environmental uncertainty and community income. Also to determine the direct influence of the government's role on environmental uncertainty and community income. The results of the analysis of the inner model of Sub-structural 2 are shown in Figure 7. 


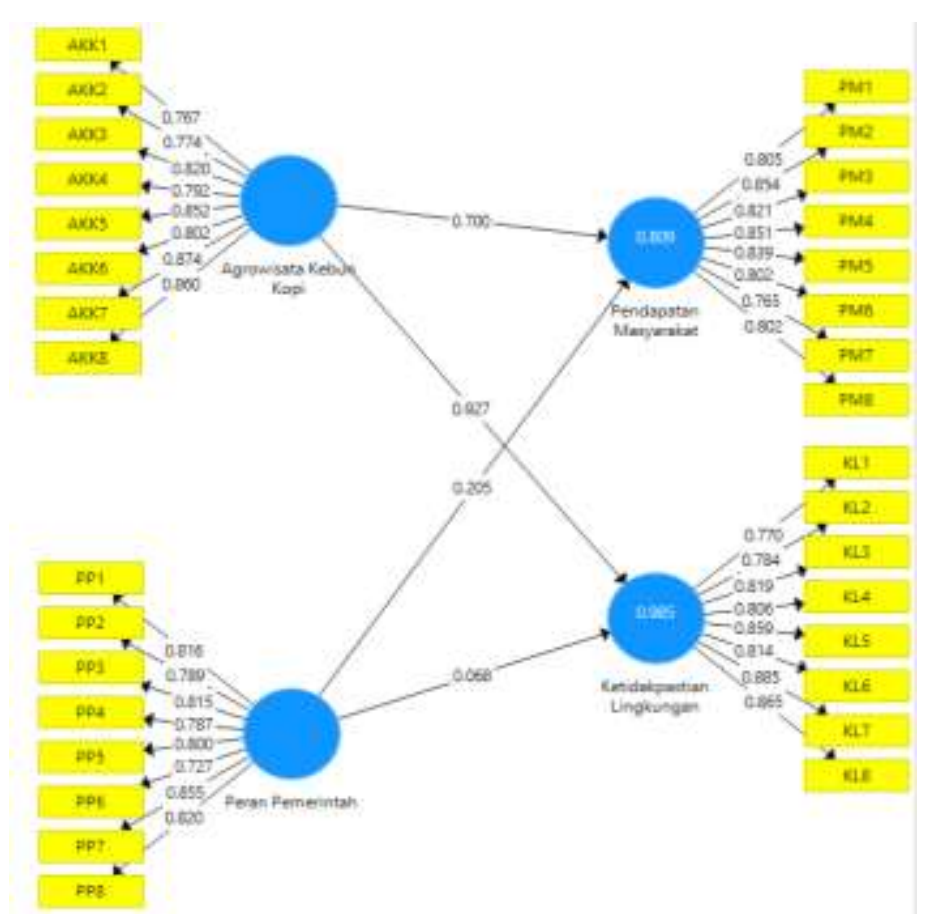

Figure 7. Inner Model Sub struktural 2

To facilitate the analysis based on the data shown in Figure 7 then summarized in Table 2.

Table 2. Testing the Significance of the Sub-structural Path Coefficient 2

\begin{tabular}{lcccc}
\hline \multicolumn{1}{c}{ Variable Relationship } & $\begin{array}{c}\text { Original } \\
\text { Sample } \\
(\mathrm{O})\end{array}$ & $\begin{array}{c}\text { Standard } \\
\text { Deviation } \\
(\mathrm{STDEV})\end{array}$ & $\begin{array}{c}\text { T Statistics } \\
(|\mathrm{O} / \mathrm{STDEV}|)\end{array}$ & $\begin{array}{c}\mathrm{P} \\
\text { Values }\end{array}$ \\
\hline $\begin{array}{l}\text { Coffee plantation agro-tourism } \\
->\text { Environmental uncertainty }\end{array}$ & 0,927 & 0,088 & 10,517 & $\mathbf{0 , 0 0 0}$ \\
\hline $\begin{array}{l}\text { Coffee Garden Agrotourism -> } \\
\text { Community Income }\end{array}$ & 0,700 & 0,158 & 4,419 & 0,000 \\
\hline $\begin{array}{l}\text { Government Role -> } \\
\text { Environmental uncertainty }\end{array}$ & 0,068 & 0,088 & 0,776 & 0,438 \\
\hline $\begin{array}{l}\text { Government Role -> } \\
\text { Community Income }\end{array}$ & 0,205 & 0,157 & 1,306 & 0,192 \\
\hline
\end{tabular}

Based on the data shown in Table 2, it can be explained that:

a) Coffee plantation agro-tourism has a significant effect on environmental uncertainty in Bener Meriah Regency and Central Aceh with a coefficient value of 0.927 and a significant value (p-value) of 0.000 (significant at the $1 \%$ level). This means that if coffee plantation agro-tourism is developed, it will increase environmental uncertainty in Bener Meriah Regency and Central Aceh.

b) It is explained that coffee plantation agrotourism has a significant effect on people's income in Bener Meriah Regency and Central Aceh with a coefficient value of 0.700 and a significant value (p-value) of 0.000 (significant at the $1 \%$ level). This means that if coffee plantation agro-tourism is developed, it will increase the income of the people in Bener Meriah Regency and Central Aceh. 
c) It is explained that the role of the government has a significant effect on environmental uncertainty in the regencies of Bener Meriah and Central Aceh with a coefficient value of 0.068 and a significant value (p-value) of 0.000 (significant at the $1 \%$ level). This means that if the government's role is increased, it will be able to minimize environmental uncertainty in Bener Meriah Regency and Central Aceh.

d) It is explained that the government's role has a significant effect on people's income in kab.bener Merry and Aceh Tengah with a coefficient value of 0.205 and a significant value (p-value) of 0.000 (significant at the $1 \%$ level). This means that if the government's role is increased, it will increase the income of the people in Bener Meriah Regency and Central Aceh.

\section{Sub structural 3}

Sub-structural 3 aims to determine the direct influence of coffee plantation agrotourism (AKK), the role of the government (PP) on community income (PM) and environmental uncertainty (LK) and the government's role in moderating the development of plantation agro-tourism on AKK*PM coffee community income. And the role of the government in moderating coffee plantation agro-tourism to the environmental uncertainty of $\mathrm{AKK}^{*} \mathrm{KL}$. The results of the analysis of the inner model of Sub-structural 3 are shown in Figure 8.

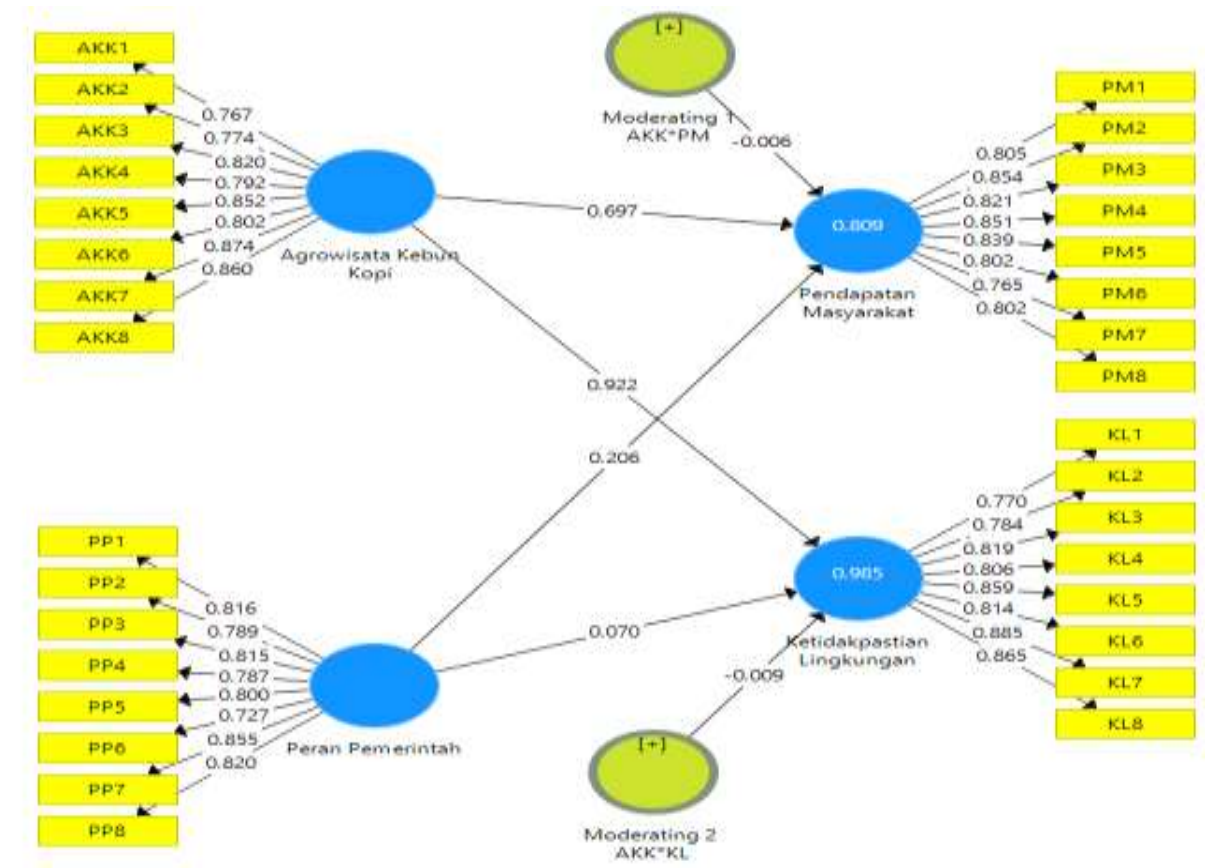

Figure 8. Inner Model Sub Structural 3

To facilitate the analysis based on the data shown in Figure 8, they are summarized in Table 3. 
Table 3. Testing the Significance of Sub-structural Path Coefficients 3

\begin{tabular}{lcccc}
\multicolumn{1}{c}{ Variable Relationship } & $\begin{array}{c}\text { Original } \\
\text { Sample (O) }\end{array}$ & $\begin{array}{c}\text { Standard Deviation } \\
(\text { STDEV })\end{array}$ & $\begin{array}{c}\text { T Statistics } \\
(|\mathrm{O} / \mathrm{STDEV}|)\end{array}$ & $\begin{array}{c}\mathrm{P} \\
\text { Values }\end{array}$ \\
\hline $\begin{array}{l}\text { Coffee Farm Agrotourism -> } \\
\text { Environmental Uncertainty }\end{array}$ & 0,922 & 0,093 & 9,909 & $\mathbf{0 , 0 0 0}$ \\
\hline $\begin{array}{l}\text { Coffee Farm Agrotourism -> } \\
\text { Community Income }\end{array}$ & 0,697 & 0,156 & 4,478 & $\mathbf{0 , 0 0 0}$ \\
\hline $\begin{array}{l}\text { Moderating 1 AKK*PM -> } \\
\text { Community Income }\end{array}$ & $-0,006$ & 0,032 & 0,190 & 0,850 \\
\hline $\begin{array}{l}\text { Moderating 2 AKK*KL -> } \\
\text { Environmental Uncertainty }\end{array}$ & $-0,009$ & 0,007 & 1,190 & 0,235 \\
\hline $\begin{array}{l}\text { Government Role -> } \\
\text { Environmental Uncertainty }\end{array}$ & 0,070 & 0,092 & 0,757 & 0,449 \\
\hline $\begin{array}{l}\text { Government Role -> } \\
\text { Community Income }\end{array}$ & 0,206 & 0,153 & 1,351 & 0,177 \\
\hline
\end{tabular}

Based on the data shown in Table 3, it can be explained that:

a) Coffee plantation agro-tourism (AKK) has a significant effect on environmental uncertainty (KP) with a coefficient value of 0.922 and a significant value (p-value) of 0.000 (significant at the $1 \%$ level). This means that if coffee plantation agrotourism develops, it will be able to minimize environmental uncertainty in Benermeriah Regency and Central Aceh.

b) Coffee plantation agrotourism has a significant effect on community income (PM) with a coefficient value of 0.697 and a significant value (p-value) of 0.000 (significant at the $1 \%$ level). This means that if coffee plantation agro-tourism develops, it will increase the income of the people in Bener Meriah and Central Aceh.

c) The role of the government has no effect on people's income with a coefficient value of 0.206 and a significance value of 0.177 where a significance value of $0.177>0.05$ means that there is no influence of the role of the government in developing coffee plantation agro-tourism on people's income.

d) The role of the government has no effect on environmental uncertainty with a coefficient value of 0.700 and a significance value of 0.449 where a significance value of $0.499>0.05$ means that there is no government influence in the development of coffee plantation agro-tourism on environmental uncertainty.

e) The role of the government does not moderate the influence of coffee plantation agrotourism on people's income and the coefficient value is -0.006 and the significant value (p-value) is 0.850 (significant at the $1 \%$ level). This means that the minus value in this coefficient shows the government's weak role in developing coffee plantation agrotourism on people's income. At the same time, the significance value $>0.05$ means that the government has not played a role in increasing community income through coffee plantation agro-tourism.

f) The role of the government does not moderate the influence of coffee plantation agrotourism on environmental uncertainty with a coefficient value of -0.009 and a significance value ( $\mathrm{p}$ value) of 0.235 (significant at the $1 \%$ level) \%). This means that the minus value in the coefficient shows the government's role is fragile in the development of coffee plantation agro-tourism against environmental uncertainty. While the significance value $>0.05$ means that the government has not played a role in minimizing environmental uncertainty in the development of coffee plantation agrotourism. 


\section{e. Coefficient of Determination ( $R$-square)}

The purpose of R-square analysis is to evaluate the prediction accuracy of a model. Evaluating how variations in the value of the dependent variable are affected by variations in the value of the independent variable in a path model. The higher the R-square value, the better the independent variable explains the dependent variable. It can also be seen from the probability value of $\mathrm{R}$-square, ie if the value is significant $\mathrm{P}$-Values $<0.05$ then the $\mathrm{R}$ square is classified as good (the independent variable is quite good in explaining the dependent variable). An R-square value of 0.75 indicates a robust research model, an Rsquare value of 0.50 indicates a moderate research model and an $\mathrm{R}$-square value of 0.25 indicates a weak research model. The results of the data analysis of the R-Square values of all structural models are shown in Table 4.

Table 4. R Square Value of Each Sub Structure

\begin{tabular}{lcc}
\hline & R Square & R Square Adjusted \\
\hline Sub Structure 1 & & \\
Environmental Uncertainty & 0.984 & 0.984 \\
Community Income & 0.806 & 0.805 \\
\hline Sub Structure 2 & & \\
Environmental Uncertainty & 0.985 & 0.984 \\
Community Income & 0.809 & 0.807 \\
\hline Sub Structure 3 & & \\
Environmental Uncertainty & 0.985 & 0.984 \\
Community Income & 0.809 & 0.805 \\
\hline
\end{tabular}

Based on the data shown in Table 4.18, it can be explained that the R-Square Value of Substructure 1, namely the coffee plantation agrotourism variable, can explain environmental uncertainty (KL) of $98.4 \%$ and the rest is explained by other variables not included in this study, namely $1,6 \%$ of the coffee plantation agro-tourism variables were able to explain community income (PM) with an R Square value of $80.6 \%$. The rest was explained by other variables not included in this study of $19.4 \%$.

Furthermore, it can be explained that the R-Square value of Substructure 2, namely the government's role variable, can explain environmental uncertainty (KL) of $98.5 \%$ (explaining power is delighted). The rest is explained by other variables not included in this study, namely 1 , The next $5 \%$, the government's role variable, can explain the community's income (PM) with an R Square value of $80.9 \%$. The rest is explained by other variables not included in this study of $19.1 \%$.

Moreover, it can be explained that the R-Square Sub structure value 3, namely the variable role of the government in moderating the relationship between coffee plantation agro-tourism, can explain environmental uncertainty (KL) of $98.5 \%$ and the rest is explained by other variables not included in this study, namely $1.5 \%$. The government's role variable as a moderating variable is able to explain people's income (PM) with an R Square value of $80.9 \%$, and the rest is explained by other variables not included in this study of $19.1 \%$.

\subsection{Discussion}

Coffee plantation agrotourism has a positive and significant effect on people's income, with a coefficient value of 0.697 and a significant value of 0.000 (significant at the $1 \%$ level). This means that if coffee plantation agro-tourism is developed as a tourist 
attraction in Bener Meriah Regency and Central Aceh, it will be able to be used as a solution for fluctuations in community income, coffee farming community income, where in the coffee harvest season people's incomes increase sharply (high) and in coffee conditions, the income has not increased. fruitful and immature, people's incomes are low. This is because most of the people work in the primary sector, namely coffee plantations. So the first hypothesis which states, "Agrotourism in coffee plantations has a significant effect on the plug-in solution for people's income", is accepted.

Based on the results of data analysis, it was found that coffee plantation agrotourism (AKK) had a significant effect on Environmental Uncertainty (KL) with a coefficient value of 0.922 and a significant value (p-value) of 0.000 (significant at the $1 \%$ level). This means that if coffee plantation agro-tourism is developed into a tourist attraction, it will solve environmental uncertainty. So the second hypothesis, which states, "Coffee plantation agro-tourism has a significant effect on environmental uncertainty in Bener Meriah and Central Aceh districts, is accepted.

Based on the results of data analysis, it was found that the role of the government (PM) did not significantly affect people's income with a coefficient value of 0.206 and a significant value (p-value) of 0.177 (significant at the $1 \%$ level). Where the $\mathrm{p}$-value $>0.05$, this means that the role of the government has not been able to increase people's income. In Bener Meriah District and Aceh are currently developing coffee plantation agro-tourism. The third hypothesis, which states "The role of the government has a significant effect on increasing the income of the community around the agro-tourism location" is rejected.

Based on the data analysis, it was found that the Government's Role (PM) had no significant effect on environmental uncertainty (KP) with a coefficient value of 0.700 and a significant value (p-value) of 0.449 (significant at the $1 \%$ level). The significance value $(\mathrm{p}=$ Value $)$ is $0.449>0.05$. This finding means that the government's role does not significantly increase environmental uncertainty. Agro-tourism locations, signs and directions to agro-tourism locations have not been carried out optimally. The fourth hypothesis, which states "The role of government has a significant effect on environmental uncertainty" is rejected.

Based on the data shown in table 4.17, it is explained that coffee plantation agrotourism has a positive and significant effect on people's income. After being controlled by moderating and interaction variables, the government's role variable does not significantly affect people's incomes. The interaction variable (moderating effect 1 ), namely moderating 1 AKK*PM -> Community income, also does not significantly affect people's income. The fifth hypothesis, which states, "The role of the government in moderating the influence of coffee plantation agro-tourism on job satisfaction has a significant effect on people's incomes in Bener Meriah and Central Aceh districts", rejected.

Based on the results of testing the moderating effect, the variable role of government (PM) does not moderate the influence of coffee plantation agrotourism on environmental uncertainty. The results of this study mean that the role of the government does not play a role in strengthening or weakening the influence of coffee plantation agro-tourism as a solution to environmental uncertainty in the districts of Bener Meriah and Aceh Tengah. In other words, it can be stated that the government's role cannot be used as a moderating variable because its influence or relationship with the solution of environmental uncertainty is not significant. The government's role can only be said to be an independent variable. Then the sixth hypothesis, which states "The role of government in moderating the influence of coffee plantation agro-tourism on environmental uncertainty in Bener Meriah and Aceh Tengah districts," is rejected. 


\section{Conclusion}

The first objective of this study was to identify and determine the direct effect of coffee plantation agrotourism on people's income and the direct influence of coffee plantation agrotourism on environmental uncertainty in Bener Meriah and Aceh Tengah districts. For this purpose, sub-structure model 1 has been used by applying the structural equation model (inner model). The results of the study found that the variable of coffee plantation agro-tourism development is an essential factor that can be used to increase people's income which is currently fluctuating because the coffee harvest influences it. The development of coffee plantation agro-tourism is also an essential factor to overcome environmental uncertainty so that farming communities can take advantage of coffee fields. As a garden that produces coffee cherries and at the same time as agro-tourism that can create new jobs, open up business opportunities and educational processes about coffee to visitors/tourists. The second objective of this research is to identify and determine the direct influence of the government's role on people's income and environmental uncertainty through coffee plantation agrotourism in Bener Meriah and Central Aceh Districts. For this purpose, sub-structure model 2 has been used by applying the structural equation model (inner model). The study results found that the variable role of the government is a factor that has not shown its influence to increase people's income and environmental uncertainty through coffee plantation agrotourism. The results showed that the government's role directly did not significantly affect people's income and environmental uncertainty. The third objective of this study is to identify and determine the direct influence of coffee plantation agro-tourism, the role of the government on people's incomes, and environmental uncertainty in the districts of Bener Meriah and Central Aceh. For this purpose, substructure model 3 has been used by applying the structural equation model (inner model). The results showed that coffee plantation agrotourism is an essential factor that can be used to overcome fluctuations in the income of coffee farming communities and environmental uncertainty to use the land as a coffee plantation and agro-tourism. The role of the government directly does not significantly affect people's income. The government's role in moderating community income and environmental uncertainty through the development of coffee plantation agro-tourism is very weak or in other words, so far, the government has not played a role in increasing community income and environmental uncertainty through coffee plantation agro-tourism in the districts of Bener Meriah and Central Aceh.

\section{References}

Alamsyah Taher. 2009. Metode Penelitian Sosial. Syiah Kuala University Press Kampus Universitas Syiah Kuala. Banda Aceh.

Astuti, N.W.W. 2013. Prospek Pengembangan Agrowisata Sebagai Wisata Alternatif di desa Pelaga. Jurnal Sosial Dan Humaniora. 3(3): 301 -311.

Avenzora R, Teguh F. 2013. Ekowisata dan Pengembangan Pariwisata Berkelanjutan diIndonesia: Potensi, Pembelajaran, dan Kesuksesan. Jakarta (ID): Kementrian Pariwisata dan Ekonomi Kreatif.

Byrne, B. M.,2001. Structural Equation Modeling With AMOS: Basic, Concepts Application, and Programming. Lawrence Erlbaum Associatesw, Inc. United States of America

Chong,V K \& Chong, K M.1997. Strategic Choices, Enviromental Uncertainty and SBU Performance: Accounting and Business Research. Vol 7 No 4. Departemen 
Pertanian.2003 Agro wisata Meningkatkan Pendapatan Petani.Warta Penelitian Dan Pengembangan Pertanian Vol.24 No 1. http //databasedeptan.go.id.agrowisata/.

Ferdinan Augusty.2006. Metode Penelitian Manajemen Pedoman Penelitian Untuk Penulisan Skripsi, Tesis dan Disertasi Ilmu Manajemen. Universitas Diponogoro. Semarang.

Firya akbar. jurnal ilmu pemerintahan issn 2442-5958 E-ISSN 2540-8674

Ghozali, I., 2008. Structural Equation Modeling Dalam Penelitian Manajemen. Edisi Kedua. Semarang: Badan Penerbit Undip.

Goeldner, Ritchie.2006. Tourism: Principles, Practies, Philosophies. Wiley: Hoboken N.

Gronau,W.and R.Kaufmann.2009.Tourism as A Stimulus for sustainable Development in Rural Areas; A Cypriot Perpective, Tourismos An International Multidisiplinary Journal of Tourism, Vol.4(1),pp.83-95,University of Nicosia.

Gunawan, Filician and Budiono, Linda (2005) Pandangan para pelaku bisnis pariwisata (biro perjalanan wisata, hotel, dan guide) mengenai Surabaya sebagai tempat tujuan wisata. Diploma thesis, Petra Christian University.

Hair JF. 2009. A Primer on Partial Least Squares Structural Equation Modeling (PLSSEM).

I gede arya sanjaya. 2017. Studi Potensi Subak Renon di Denpasar Selatan untuk Pengembangan Agrowisata. E-Jurnal Agroekoteknologi Tropika. Vol. 2, No. 1.

Indah Purnama Sari. Dr. Alamsyah Taher, M.Si. 2017. Pengembangan Agrowisata Kebun Kopi Pada Masyarakat Kampung Jamur Ujung Kecamatan Wih Pesam Kabupaten Bener Meriah. Jurnal Ilmiah Mahasiswa FISIP Unsyiah. Vol.3 No. 1 www.jim.unsyiah.ac.id.

Iqbal Arisa, Mahdi Syahbandir. 2019. Kebijakan Pemerintah Aceh Tengah dalam Pengembangan Sektor Pariwisata. Jurnal Ilmiah Mahasiswa FISIP Unsyiah Volume 4, Nomor 1, Februari 2019 www.jim.unsyiah.ac.id /FISIP

Lopez, E.P and F.J.C. Gracia.2006. Agrotourism,sustainable tourism and Ultraperipheral areas: The Case of Canary Island Journal, Vol.4(1),pp.85-97

Magdalena, S., Suhatman, R. (2020). The Effect of Government Expenditures, Domestic Invesment, Foreign Invesment to the Economic Growth of Primary Sector in Central Kalimantan. Budapest International Research and Critics Institute-Journal (BIRCIJournal). Volume 3, No 3, Page: 1692-1703.

Mill, Morisson. 2000. The Tourism System. New Jarsley: Prentice Hall International

Milliken, F. J. 1987. Three Types of Perceived Uncertainty about Environment: State, Effect and Response Uncertainty. Academy of Management Review 12, pp. 133-143.

Niwayan Karisnawati. 2018. Potensi dan Strategi Pengembangan Agrowisata Kopi Luwak Teba Sari Balidi Desa Lodtunduh, UBUD, Denpasar.

Oka A. Yoeti. 2008. Perencanaan dan Pengembangan Pariwisata. Balai Pustaka. ISBN 9794083932

Oman Sukirman. 2017. Apakah Anggaran Pemasaran Pariwisata Pemerintah Efektif dalam Meningkatkan Jumlah Kunjungan Wisatawan. Tourism and Hospitality Essentials (THE) Journal, Vol. 7, No. 2, 2017 - 121

P.N.H. Simanjuntak, S.H.,Pokok-Pokok Hukum Ierdata Indonesia, Djambatan, Jakarta, 2008.

Pitana, I Gede dan Gayatri, Putu Gede. 2005. Sosiologi Pariwisata. Yogyakarta: Andi.

Rumengan Jemmy. Metodologi Penelitian. (CV. Sefa Bumi Persada-Aceh, 2020), p. 52.

Sandryas Alief Kurniasanti.2019. Analisis Strategi Pengembangan Agrowisata (Studi Kasus Kampung Petani Buah Jeruk Siam di Kecamatan Bangorejo - Banyuwangi). Journal of Tourism and Creativity. Vol.3 No.2 
Shah, M. M., et al. (2020). The Development Impact of PT. Medco E \& P Malaka on Economic Aspects in East Aceh Regency. Budapest International Research and Critics Institute-Journal (BIRCI-Journal). Volume 3, No 1, Page: 276-286

Soerjono Soekanto, Sosiologi Sesuatu Pengantar, (Jakarta: Rajawalipres, 2012.)

Spillane J. 1994. Ekonomi Pariwisata: Sejarah dan Prospeknya. Yogyakarta (ID): Kanisius. Sudjana. 2005. Metode Statiska. Bandung: Tarsito.

Sugiyono. 2011. Metode Penelitian Kuantitatif. Aflabeta. Bandung.

Surya, Yohanes. 2008. Prediksi Ekonofisik/Kompleksitas, Banten: Kandel.

Syamsiar.2007. Model Pengembangan Agrowisata Pedesaan Sebagai Basis Pembangunan Masyarakat (Kajian Agrowisata Di Desa Tanjung Kecamatan Ngaglik Kabupaten Sleman Diy) Vol 4 No 1. https://jurnal.uns.ac.id

Utama, I.G.B.R. 2012. Agrowisata Sebagai Pariwisata Alternatif Indonesia [Internet]. Buku Referensi: Penerbit Deepublish. [diunduh 11 Mei 2021]. Tersedia pada: https://penerbitdeepublish.com/agrowisata

Vendi Yhulia Susanto.2020. Sepanjang 2019, Devisa Sektor Pariwisata Mencapai Rp.280 Triiun. Referensi: https://nasional.kontan.co.id .2020)

Wall, G. 1997. Substainable Tourism Unsusbstainable Development. In S.Wahab Pigram London Raunledge

Yani Alfian. 2019. Peran Pemerintah Desa Dalam Meningkatkan Pelayanan Publik Kepada Masyarakat Di Desa Ciharashas Kabupaten Bandung Barat. Urnal Ilmu Sosial Dan Ilmu Politik Volume 3 No. 1.

Yulistriani. 2009. Strategi Pengembangan Agrowisata Pada Perkebunan Teh Pt Mitra Kerinci Nagari Lubuk Gadang Selatan Kecamatan Sangir Kabupaten Solok Selatan. Skripsi. Fakultas Pertanian Universitas Andalas. Padang. 